\title{
Relationship Between Motivation and Extrinsic Motivation to Icreasing Entrepreneurship Implementation From SPP AL-FALAH Group at Blok 10 Village Dolok Masihul
}

\author{
${ }^{1}$ Maulana Majied Sumatrani Saragih, ${ }^{2}$ Ummul Hikmah Saragih, ${ }^{3 *}$ Rico Nur Ilham \\ ${ }^{1}$ Universitas Darma Agung, Pascasarjana Universitas Darma Agung, Jalan DR. TD Pardede No 21, \\ Medan, 20153, Sumatera Utara. \\ maulanamajied494@gmail.com
}

${ }^{2}$ Universitas Andalas, Limau Manis, Kec. Pauh, Kota Padang, Sumatera Barat 25175 ummulhsaragih1511@gmail.com

${ }^{3}$ Faculty of Economic and Business Universitas Malikusaleh, Lhokseumawe, Aceh, Indonesia riconurilham@unimal.ac.id

Corresponding Author: riconurilham@unimal.ac.id

\begin{abstract}
This study aims to determine how the influence of Intrinsic Motivation and Extrinsic Motivation on Entrepreneurial Interest in the SPP (Women's Savings and Loans) Group. The research method used is the method of qualitative data and quantitative data. While the data used is primary data. The data analysis method in this study uses multiple linear regression analysis to obtain a comprehensive picture of the influence between the variables of Intrinsic Motivation and Extrinsic Motivation on Entrepreneurial Interest by using the SPSS 17 for Windows program. To find out whether there is a significant effect of the independent variable on the dependent variable, the multiple linear regression model is used. The results of hypothesis testing using multiple regression analysis and t-test indicate that: that the t-table value of the Intrinsic Motivation variable is 10,064 > the t-table value (df: 58, :5\%) of 2.0017 so it can be concluded if Intrinsic Motivation has an effect positive and significant towards Entrepreneurial Interest. Furthermore, from table 4.11 it can also be seen that the t-table value of the Extrinsic Motivation variable is 1.224 < the t-table value (df: 58, :5\%) of 2.0017 so it can be concluded that Extrinsic Motivation has no significant effect on Entrepreneurial Interest.
\end{abstract}

\section{Keywords : Intrinsic Motivation, Extrinsic Motivation dan Entrepreneurial Interest}

\section{INTRODUCTION}

Interest in entrepreneurship is an encouragement both from within and from the environment for someone to do a business in order to improve the economy and increase economic income where this motivation can be separated into two groups, namely intrinsic motivation and extrinsic motivation. The term motivation comes from the Latin word movere, which means "to move" (to move). The theory developed by Hezberg is known as the "TwoFactor Model" of motivation, namely motivational factors and hygiene or "maintenance" factors. Interest in entrepreneurship according to Longenecker's (2008) theory says that 
everyone who intends to become an entrepreneur is due to an internal drive and there are factors behind it. Motivational factors are things that encourage achievement that are intrinsic, while what is meant by hygiene or maintenance factors are factors that are extrinsic.

One of the challenges in understanding and applying Herzberg's theory is to take into account exactly which factors are more powerful in a person's life, whether intrinsic or extrinsic. Motivation is an encouragement that comes from within a person's soul which is very necessary because motivation is the thing that causes, distributes and supports human behavior, so that they want to work enthusiastically to achieve optimal results. Intrinsic motivation is motivation that arises from within a person, there is no need for external encouragement. From within a person there is an urge that causes them to do something they want to get what they want. Extrinsic motivation is motivation that comes from outside one's self and is obtained from other people, motivation does look easy but someone will rise up with motivation from other people who are smarter or older than them but motivation can also arise from people who are younger or the same age as that person.

SPP (Women's Savings and Loans) Mpd is one of the government programs to improve the welfare of its people in the economic field, especially in the field of entrepreneurship, SPPPNPM is a program created during the era of President Susilo Bambang Yudhoyono (SBY). This program was created due to the increasing household needs so that with this program, especially for women, it can help the economic needs of the household. The SPP is divided into 2 types, one is for village development and one is for women's savings and loans, but in the era of Mr. Jokowi, Pnpm has been separated, especially in the village development program because it has been changed and updated with a new program name. However, the SPP program from the government of Mr. SBY was not immediately removed during the era of President Jokowi. The SPP is still running, especially in rural areas, as the government's initial goal was to prosper the community.

Precisely the object of my research is the independent PNPM group in Blok 10 Village, Dolok Masihul Kab. Serdang Bedagai, where the rural SPP Mandiri group often holds meetings and associations to carry out micro-medium entrepreneurship activities. This activity is carried out in accordance with the government's program to improve the welfare of women. In this case the head of the SPP group plays an active and important role in providing motivation both internally and externally for its members. SPP Desa Blok 10 often invites resource persons who are competent in the field of entrepreneurship, to provide motivation and enthusiasm in carrying out entrepreneurial activities, presumably in order to gain knowledge and knowledge in stepping into entrepreneurship. Pnpm members also play a role in advancing their groups to create the desired goals for the welfare of the SPP groups.

I see what is the benchmark for housewives, especially women to participate and join the rural independent SPP program, whether it's the intrinsic motivation that is contained in the spirit of the spirit in increasing the economic needs of the family or the extrinsic motivation that is encouraged by friends and family. living environment so that housewives want to join the government program, namely SPP Mandiri Rural. Motivation is increasingly important because the head of the pnpm group distributes work to its members to be done well and integrated to the desired goal. Good motivation reflects the magnitude of the responsibility of the group leader in fostering and directing its members. Intrinsic and extrinsic motivation is one of the important components in achieving the success of a work process both individual groups and companies. Because it contains a driving element for someone to do work alone or in groups. 
An encouragement that comes from outside itself, in the form of self-awareness to work better or to give the best for the group by having a positive impulse, they need to be assisted by other people who act as leaders or superiors. One of the activities that make it easier for marginalized people to get capital is in the form of SPP (Women's Savings and Loans) activities, providing for capacity building for productive economic enterprises, providing grants for funding business facilities and working capital for 1 business cycle in the form of capacity building activities. women's group business, explained in the type and process of implementing the field of activity.

Usually what women's groups do to help their families is as planting laborers when the planting season arrives, as casual daily laborers in factories when many orders arrive. Alhamdulillah, with the Women's Savings and Loans (SPP) in the village of block 10, Dolok Masihul sub-district, Serdang Bedagai district.

The list of the number of group members who have businesses and what the businesses are are as follows::

Table 1.1 :

List Number of Members Who Own a Business

\begin{tabular}{ccclcc}
\hline No & $\begin{array}{c}\text { Number of } \\
\text { Borrowers }\end{array}$ & Address & Business & $\begin{array}{c}\text { Average } \\
\text { Loan/Person }\end{array}$ & Total \\
\hline 1 & 43 & Village Blok 10 & Trade & $\operatorname{Rp~10.000.000~}$ & $\operatorname{Rp~43.000.000~}$ \\
2 & 38 & Village Blok 10 & raising & $\operatorname{Rp~} 10.000 .000$ & $\operatorname{Rp~38.000.000~}$ \\
3 & 52 & Village Blok 10 & Agriculture & $\operatorname{Rp~10.000.000~}$ & $\operatorname{Rp~52.000.000~}$ \\
4 & 17 & Village Blok 10 & Culinary & $\operatorname{Rp~10.000.000~}$ & $\operatorname{Rp~17.000.000~}$ \\
Total & 150 & Village Blok 10 & Entrepreneur & - & $\operatorname{Rp~150.000.000~}$ \\
\hline
\end{tabular}

Source : PNPM Mandiri Village Blok 10

Based on the results of the rural independent women's savings and loan revolving fund, members get the benefits of economic activity in the form of entrepreneurship, the facts that occur in the field after receiving funds from Rural Mandiri SPP there are some SPP members who trade, raise livestock and capital for agriculture, but there are also those who do entrepreneurship, for example these funds some are used for culinary business activities.

\section{LITERATURE REVIEW}

\subsection{Entrepreneur}

According to Zimmerer (2009: 4), an entrepreneur is someone who is able to innovate a new business by taking risks and uncertainties in order to achieve profit and growth by identifying opportunities and combining the necessary resources to establish them. Researchers have spent a great deal of time and effort in the last decade to get a clear picture of this. According to Kasmir (2010), entrepreneurs are people who have the courage to take risks to open businesses on various occasions. Having the courage to take risks means being mentally independent and daring to start a business, without being overwhelmed by fear or anxiety even in uncertain conditions. An entrepreneur in his mind is always trying to find, take advantage of, and take advantage of business opportunities that can provide profits.

According to Sukirno (2008:369), the meaning and definition and views of entrepreneurship are heavily influenced by economic, psychological and sociological 
considerations. A person who is very determined to be in the field of companies can be driven by his own desire (psychology) which is based on form and way of thinking. A person's decision to trade is also based on economic needs and because of the people around him who are potential customers.

\subsection{Women Entrepreneur}

According to Zimmerer and Scarborough (2008:26), even though it has been fought for years to be able to legislate, a woman still experiences discrimination in the workplace. Nonetheless, small businesses have been pioneers in offering economic opportunities both employment and entrepreneurship. One writer says, "Entrepreneurship has become as unisex as jeans, where women are here to develop their biggest dreams and hopes". More and more women are realizing that being an entrepreneur is the best way to break through the male dominance that hinders their career advancement time to the top of the organization through their own business.

\subsection{Entrepreneurial Interest}

According to Amalia and Hadi (2016: 764) interest in entrepreneurship is the availability to work hard and diligently to achieve business goals. Willingness to bear various risks associated with entrepreneurship and a strong will to be independent or trying to fulfill their needs without being afraid of the risks that will occur and learning from failure. Meanwhile, according to Ramadhani and Nurnida (2017: 93) interest in entrepreneurship is encouragement, interest and hard work, a strong will to be independent or trying to meet needs and be brave with the risks that may be experienced, as well as a strong determination to learn from failure.

According to Aprilianty's (2012:312) interest in entrepreneurship is a competency to take planned risks to overcome obstacles and achieve the desired success with limited resources. Interest in entrepreneurship can also be interpreted as an interest in entrepreneurship, willingness to be involved in entrepreneurship activities, courage in facing risks, courage in facing challenges, feelings of pleasure in entrepreneurial activities, desire to realize ideals in entrepreneurship (Christianingrum and Rosalina, 2017: 49). ). Interest in entrepreneurship is the desire, interest, and willingness of individuals to work hard in meeting their needs without fear of the risks that will occur (Anggraeni et al., 2015: 2), and according to Bygrave, interest in entrepreneurship does not come from birth, but grows in harmony with factors that influence entrepreneurship. influence entrepreneurship. Factors that influence the emergence of decisions to become entrepreneurs are the results of interactions with a number of factors, namely the environment and individual character.

\subsection{Intrinsic Motivation}

According to Priyatama (2009), intrinsic motivation is the value or combination of enjoyment or pleasure in carrying out a task to achieve success For certain purposes, it can be said that the intrinsic motivation that functions as a reward is the individual's behavior in carrying out these activities, not external rewards. Suwatno (2011:175) states "intrinsic motivation is motives that become active or function do not need to be stimulated from outside, becauseIn every individual there is an urge to do something. according to Husaini Usman (2009:249) defines "intrinsic motivation is motivation that arises from within oneself". 
According to Herberg in Rosidah (2009: p.241), said that there are groups of intrinsic condition factors which include: achievement, recognition, responsibility, progress of the employee himself, the possibility of developing. The absence of this condition does not mean that the condition is not satisfied, but if such conditions exist, it is a strong motivation that will result in good performance. Intrinsic factors are drivers that come from outside a person, especially from the organization where he works. According to this theory, the factors that drive aspects of motivation are success, recognition, the nature of the work for which one is responsible, opportunities for advancement, and growth. Hygiene factors that stand out are company policies, supervision, working conditions, wages/salaries, relationships with coworkers, personal life, relationships with subordinates, status, and security.

\subsection{Extrinsic Motivation}

Permana (2009) quotes from Nawawi explaining that extrinsic motivation is a work driver that comes from outside the worker as an individual, in the form of a condition that requires carrying out work to the fullest. According to Manullang (2001) it is stated that if the company provides insufficient working conditions, wages, benefits or safety, it will have difficulty attracting good employees and turnover and absenteeism will increase.

Marjani (2005) suggests that there is a positive relationship between motivation and employee performance. In this study, it was found that the high condition of employee work motivation was related to the tendency of achieving a fairly high level of employee performance. Employees who have high motivation, they will try to do as much as possible the goals set.

\section{RESEARCH METHODS}

The method of data collection using the Questionnaire method is carried out by distributing a list of questions containing 15 questions to the SPP Group Members in Block 10 Village. The technique of collecting data by interview is a technique of collecting data by using oral questions to research subjects. This is done to get an overview of the problems that usually occur due to special causes that cannot be explained by a questionnaire.

Data obtained through direct research to the object of research either by questionnaires or direct interviews which still have to be processed by the author. Sources of data used in this study is primary data collected directly from the source, observed, and recorded for the first time by the researcher. Primary data is also obtained by visiting and interviewing respondents directly using a list of questions (questionnaires) that have been prepared previously.

The population of all data is of concern to us within a specified scope and time. Population is a generalization area consisting of objects/subjects that have certain qualities and characteristics determined by the researcher to be studied and then draw conclusions (Sugiono, 2008,115). The population in this study were all SPP groups in Blok 10 Village, Dolok Masihul District, Serdang Bedagai Regency, which amounted to 150 people. By using an error rate of $10 \%$, the size of the sample taken from a population of 150 people in this study was determined by the Slovin formula, namely 60 people..

In analyzing the data obtained, the authors conducted an analysis of the data in question. This research is a quantitative research because the data obtained will be processed in the form of numbers. In this study, the authors look at the relationship of variables to the object under 
study which are more causal in nature and look for how big the role of the independent variable is to the dependent variable.

\section{DISCUSSION RESULT}

\subsection{Normality test}

Normality test aims to test whether in the regression model, the confounding or residual variables have a normal distribution (Ghozali, 2016:154). Testing the normality of the data can be done using two methods, graphs and statistics. The normality test of the graph method using the statistical method using one sample Kolmogorov Smirnov Test.

Table 4.1. Uji One Sample Kolmogorov Smirnov Test

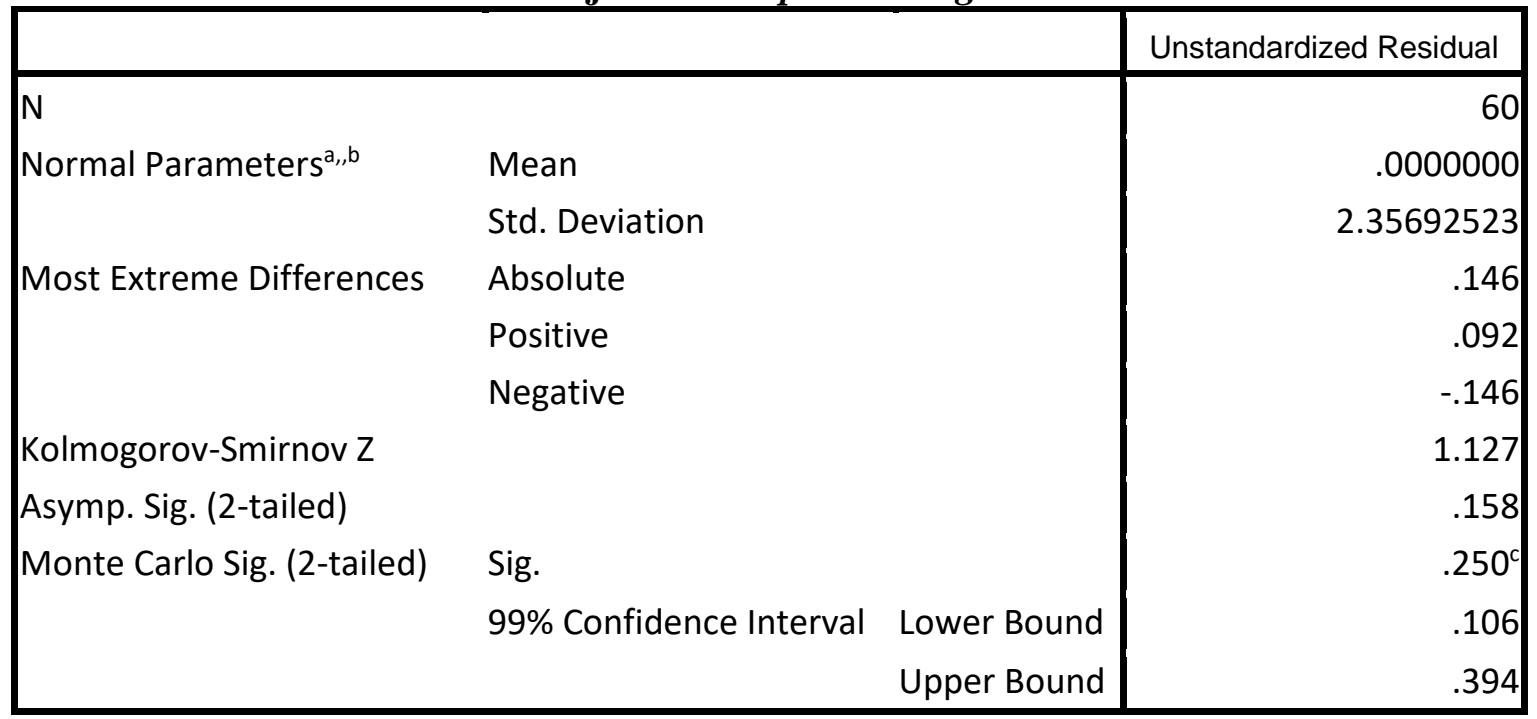

a. Test distribution is Normal.

b. Calculated from data.

c. Based on 60 sampled tables with starting seed 2000000.

Source : Processed data SPSS 17 (2021)

It can be seen that the significance value (Monte Carlo Sig.) of all variables is 0.250. If the significance is more than 0.05 , then the residual value is normal, so it can be concluded that all variables are normally distributed.

\subsection{Multicollinearity Test}

The multicollinearity test aims to determine whether there is a correlation between the independent variables in the regression model. The multicollinearity test in this study is seen from the tolerance value or variance inflation factor (VIF).

The calculation of the tolerance value or VIF with the SPSS 17.00 program for windows can be seen in Table 4.2 below:

Table 4.2 Multicollinearity Test Results

Coefficients $^{\mathrm{a}}$ 


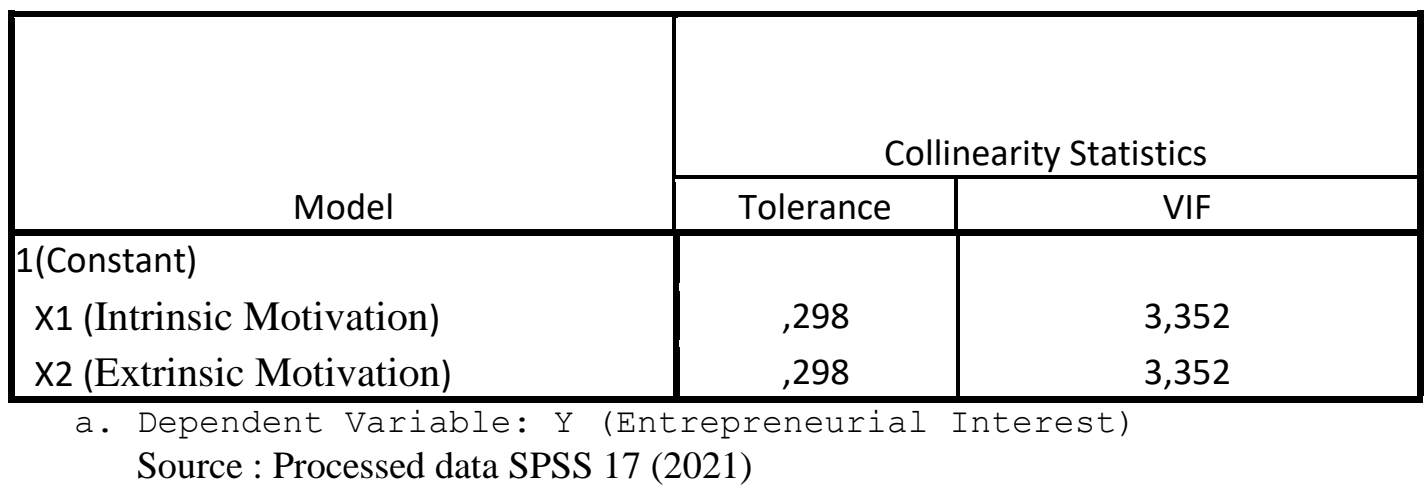

Based on table 4.2, it can be seen that the tolerance value of the Entrepreneurial Interest variable is 0.298 , the Trust variable is 0.298 , all of which are greater than 0.10 , while the VIF value of the Entrepreneurial Interest variable is 3.352, the Trust variable is 3.352, all of which are less than 10. the calculation results above can be seen that the tolerance value of all independent variables is greater than 0.10 and the VIF value of all independent variables is also smaller than 10 so that there is no correlation symptom in the independent variables. So it can be concluded that there is no symptom of multicollinearity between independent variables in the regression model.

\subsection{Heteroscedasticity Test}

The heteroscedasticity test aims to test whether from the regression model there is an inequality of variance from the residuals of one observation to another observation. A good regression model is one with homoscedasticity or no heteroscedasticity. One way to detect the presence or absence of heteroscedasticity is by using a scatterplot. Based on the results of data processing, the heteroscedasticity test in this study is shown in Figure 4.1 below:

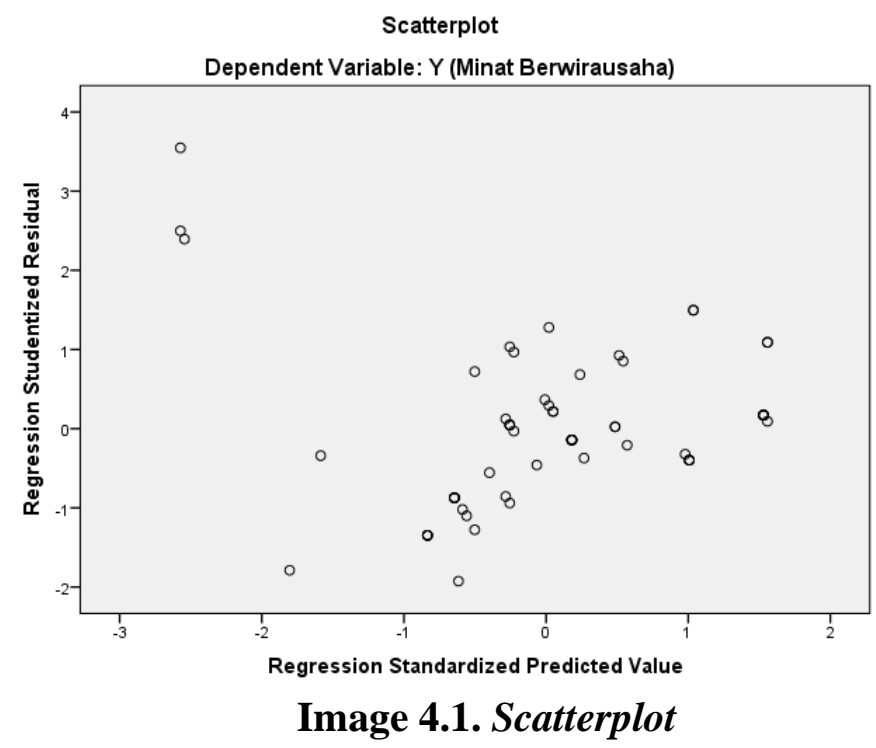

Based on Figure 4.1, it can be seen that if the data pattern is perfectly distributed, some are above the zero point and some are spread below the zero point. Because it can be guaranteed that there are no symptoms of heteroscedasticity in the regression model. 


\subsection{Multiple Linear Regression Test}

Multiple linear regression testing explains the magnitude of the role of Variable X1 and Variable X2 on Variable Y. Data analysis in this study uses multiple linear regression analysis using SPSS 17.0 for windows. The analysis of each variable is described in the following description:

\section{Table 4.3. Multiple Linear Regression Results}

Coefficients $^{\mathrm{a}}$

\begin{tabular}{|l|r|r|r|}
\hline \multirow{2}{*}{ Model } & \multicolumn{2}{|c|}{ Unstandardized Coefficients } & Standardized Coefficients \\
\cline { 2 - 4 } & \multicolumn{1}{|c|}{ B } & Std. Error & \multicolumn{1}{|c|}{ Beta } \\
\hline 1 (Constant) & 5,092 &, 757 &, 849 \\
X1 (Intrinsic Motivation) &, 674 &, 067 &, 103 \\
X2 (Extrinsic Motivation) &, 078 &, 064 & \\
\hline
\end{tabular}

a. Dependent Variable: $Y$ (Entrepreneurial Interest)

Source : Processed data SPSS 17 (2021)

Based on these results, the multiple linear regression equation has the formulation: $\mathbf{Y}=\mathbf{a}$ $+\mathbf{b} 1 \mathrm{X} 1+\mathbf{b} 2 \mathrm{X} 2+$, so that the equation is obtained: $\mathrm{Y}=\mathbf{5 . 0 9 2}+\mathbf{0 . 6 7 4 X 1}+\mathbf{0 . 0 7 8 X 2}$

\subsection{Coefficient Determination $\left(R^{2}\right)$}

The coefficient of determination is used to see how much the independent variable contributes to the dependent variable. In other words, the value of the determinant coefficient is used to measure the contribution of the studied variables $\mathrm{X}$ and $\mathrm{Y}$ as the dependent variables. The greater the value of the coefficient of determination, the better the ability of variable $\mathrm{X}$ to explain variable $\mathrm{Y}$. If the determination (R2) is greater (closer to 1), it can be said that the influence of variable $\mathrm{X}$ is large on variable $\mathrm{Y}$.

This is because the adjusted $R$ square value is not susceptible to the addition of independent variables. The value of the coefficient of determination can be seen in Table 4.4 below:

Table 4.4. Coefficient of Determination

\begin{tabular}{|l|l|l|l|l|}
\hline Model & & Model Summary & $\begin{array}{l}\text { Std. Error of the } \\
\text { Estimate }\end{array}$ \\
\hline 1 & $R$ & R Square & Adjusted R Square & 1,034 \\
\hline
\end{tabular}

a. Predictors: (Constant), X2 (Intrinsic Motivation), X1 (Extrinsic Motivation)

Source : Processed data SPSS 17 (2021)

Based on table 4.4, it can be seen that the adjusted $\mathrm{R}$ square value is 0.874 or (87.4)\%. This shows that Variable X1 and Variable X2 can explain Variable Y by (87.4)\%, the remaining $(12.6) \%(100 \%-87.4 \%)$ is explained by other variables outside this research model.

\subsection{Partial Test $(t)$}

The $t$ statistic test is also known as the individual significance test. This test shows how far the influence of the independent variable partially on the dependent variable. In this study, 
partial hypothesis testing was carried out on each independent variable as shown in Table 4.5 below:

Table 4.5. Partial Test (t)

Coefficients $^{\mathrm{a}}$

\begin{tabular}{|c|c|c|c|}
\hline & Model & $\mathrm{t}$ & Sig. \\
\hline \multirow[t]{3}{*}{1} & (Constant) & 6,726 & ,000 \\
\hline & X1 (Intrinsic Motivation) & 10,046 &, 000 \\
\hline & X2 (Extrinsic Motivation) & 1,224 & 226 \\
\hline
\end{tabular}

a. Dependent Variable: $Y$ (Entrepreneurial Interest)

Source : Processed data SPSS 17 (2021)

a. From the description it can be seen that tcount (10.064) $>$ ttable (2.0017), as well as the significance value of $0.000<0.05$, it can be concluded that the first hypothesis is accepted, meaning that the Intrinsic Motivation Variable (X1) has an effect on the Entrepreneurial Interest Variable (Y).

b. From this description, it can be seen that tcount $(1.224)<$ ttable $(2.0017)$, as well as the significance value of $0.226>0.05$, it can be concluded that the second hypothesis is not accepted, meaning that the Extrinsic Motivation Variable (X2) has no significant effect on the Interest Variable. Entrepreneurship (Y)

\subsection{Simultaneous Test (F)}

The F statistical test basically shows whether all the independent variables included in the model have a joint effect on the dependent variable. The results of this F-Test calculation can be seen in Table 4.6 below:

Table 4.6. Simultaneous Test $(\mathrm{F})$

ANOVAa

\begin{tabular}{|l|r|r|r|r|r|}
\hline \multicolumn{1}{|c|}{ Model } & Sum of Squares & df & Mean Square & F & Sig. \\
\hline 1 & 440,733 & 2 & 220,367 & 206,199 &, $000^{b}$ \\
Regression & 60,917 & 57 & 1,069 & & \\
Tesidual & 501,650 & 59 & & & \\
\hline
\end{tabular}

a. Dependent Variable: $Y$ (Entrepreneurial Interest)

b. Predictors: (Constant), X2 (Extrinsic Motivation), X1 (Intrinsic Motivation)

Source : Processed data SPSS 17 (2021)

The form of hypothesis testing based on statistics and curves can be described as follows:

a. Based on Table 4.6, it is found that the Fcount value is 206.199 with a significant level of 0.000 which is smaller than an alpha of 0.05 (5\%). The resulting Fcount of 206.199 is greater than Ftable which is 3.35. The provisions of table $\mathrm{F}$ are obtained from the number of samples reduced by the number of variables, namely df $2=n-k=60-3=57$, and the number of variables is reduced by 1 , so that $\mathrm{df} 1=\mathrm{k}-1=3-1=2$. And the results obtained from table 
$\mathrm{F}$ is 3.35. Thus, simultaneously intrinsic motivation and extrinsic motivation have a significant effect on interest in entrepreneurship.

\subsubsection{Hypothesis Development Results}

a. Hypothesis Testing the Effect of Intrinsic Motivation Variables (X1) on Entrepreneurial Interest Variables (Y).

Intrinsic motivation, a person's interest in entrepreneurship is also influenced by knowledge about entrepreneurship itself. An entrepreneur will not succeed if he does not have the knowledge, ability, and will. This is according to what Suryana (2009:82) stated that to be a successful entrepreneur, the main requirement that must be possessed is to have an entrepreneurial spirit and character. The entrepreneurial spirit and character are influenced by skills, abilities, or competencies. Competence itself is determined by business knowledge and experience.

b. Hypothesis Testing the Effect of Extrinsic Motivation Variables (X2) on

Entrepreneurial Interest Variables (Y)

Extrinsic motivation is different from intrinsic motivation because in this motivation the student's desire for online entrepreneurship is strongly influenced by external encouragement or stimulation. According to Sardiman (2006), extrinsic motivation is active and functioning motives due to external stimuli or encouragement. Extrinsic motivation can generate intrinsic motivation, so extrinsic motivation is needed in strengthening the achievement of the goals that have been set.

According to Suhardi (2013), extrinsic motivation is motivation that arises due to influences from outside the person. This motivation has a trigger to make someone motivated. These triggers can be in the form of money, bonuses, incentives, promotions, awards, praise and so on. Extrinsic motivation has the power to change a person's will from not wanting to do something.

c. Intrinsic Motivation Variable (X1), Extrinsic Motivation Variable (X2), have a significant effect simultaneously (simultaneously) on Entrepreneurial Interest Variable (Y).

Interest in entrepreneurship is a sense of interest in entrepreneurial activities that create a business that is beneficial for oneself and the surrounding environment. Interest in entrepreneurship is influenced by the presence of high soft skills because being an entrepreneur requires various skills and strong personal characters. Entrepreneurship will make a person not dependent on others because being an entrepreneur has the freedom to achieve the goals you dream of. This freedom can be in the form of being free to determine the desired business, being free to set an operational schedule, and of course being free to determine the amount of profit you want. This freedom will make someone interested or interested in becoming an entrepreneur.

In addition, entrepreneurship can help the government in overcoming unemployment because it will create new jobs that can accommodate prospective workers. This will benefit the community, especially the community where the business is founded. The factors that influence the interest in entrepreneurship are high income expectations, support from the family environment and education accepted entrepreneurship. The indicators used include not being dependent on others, helping the social environment and feeling happy to be an entrepreneur.

\section{CONCLUSION}


Based on the results of research and discussion in the previous chapter, it can be concluded as follows:

a. Testing the first hypothesis, with a partial test analysis, the results showed that intrinsic motivation had a positive and significant effect on entrepreneurial interest with a regression coefficient of 0.674 with a positive sign $(+)$ which indicates a unidirectional relationship, meaning that if intrinsic motivation is increased it will affect entrepreneurial interest in the SPP Al Group. -Falah.

b. Testing the second hypothesis, with partial test analysis, the results obtained that extrinsic motivation has a positive and insignificant effect on entrepreneurial interest with a regression coefficient of 0.078 with a positive sign (+) which indicates a unidirectional relationship, meaning that if extrinsic motivation is getting better, it will not affect the increase in interest. Entrepreneurship Al-Falah SPP Group.

c. Testing the third hypothesis, with simultaneous analysis, the results showed that simultaneously intrinsic motivation and extrinsic motivation had a significant effect on entrepreneurial interest in the Al-Falah SPP Group.

\section{SUGGESTIONS AND ACKNOWLEDGMENTS}

To increase women's intrinsic motivation for entrepreneurship, the SPP Al-Falah group should further socialize the economic benefits of mothers who can help the family economy through entrepreneurship. To increase the extrinsic motivation of women to become entrepreneurs, the SPP Al-Falah group should offer various kinds of loans with cheap installments for its members. To increase women's interest in entrepreneurship, the SPP AlFalah group should give rewards to women who have successful businesses.

Thank you very much to the entire CV team. Express Consulting who has been able to carry out our dreams to create our own journal publishing. And thanks to our boss Dr. Rico Nur Ilham, S.E, M.M, RSA, CPRM as the owner of CV.Express Consulting who has facilitated the process of publishing this scientific article and also especially to the journal manager at $\mathrm{CV}$. Radja Publica who is willing to cooperate in the process of publishing articles on Financial Performance. I personally Maulana Majied Sumatrani Saragih, S.E, M.M, CPRM would like to say a thousand thanks to all the teams who work at CV. King of Publics.

\section{Reference}

Amalia Hadi, Dawati., Tri Supadmin, Aida Fitri. 2016. Kegiatan Ekstrakurikuler Tari Tradisional Meusaree-Saree Di Sdit Al-Fityan Lampeuneurut Aceh Besar. Jurnal Ilmiah Mahasiswa Program Studi Pendidikan Seni Drama, Tari dan Musik Fakultas Keguruan dan Ilmu Pendidikan Unsyiah Volume III, Nomor 1:22-31.

Anggraeni, S K dkk. 2015. Hubungan Kualitas Lingkungan Fisik Rumah Dan Perilaku Kesehatan Dengan Kejadian Tb Paru di Wilayah Kerja Puskesmas Gondanglegi Kecamatan Gondanglegi Kabupaten Malang. Jurnal Kesehatan Masyarakat. Volume 3 Nomor 1 Januari 2015 (ISSN : 2356 - 3346). Universitas Diponegoro.

Aprilianty, Eka. 2012. Pengaruh Kepribadian wirausaha, pengetahuan Kewirausahaan, dan Lingkungan Terhadap Minat Berwirausaha Siswa SMK. Yogyakarta: Universitas Negri Yogyakarta.

Christianingrum \& Rosalina, E. (2017). Pengaruh pembelajaran kewirausahaan terhadap minat ber-wirausaha. Integrated Journal of Business and Economic, 1(1), 44-55.

Ghozali, Imam. 2016. Aplikasi Analisis Multivariete Dengan Program IBM SPSS 23 (Edisi 8). Cetakan ke VIII. Semarang : Badan Penerbit Universitas Diponegoro. 
Herzberg, Frederick. 2011. Herzbergees Motivation-Hygiene Theory and Job Satisfaction in The Malaysian Retail Sector: The Mediating Effect Of Love Money. Sunway University Malaysia: Teck Hang Tan and Amna Waheed.

Husaini, Usman.2009. Metodologi Penelitiam Sosial. Jakarta : Bumi Aksara.

Ilham, Rico Nur et all. (2019). Investigation of the Bitcoin Effects on the Country Revenues via Virtual Tax Transactions for Purchasing Management. International Journal of Suplly Management.Volume 8 No.6 December 2019.

Ilham, Rico Nur et all. (2019). Comparative of the Supply Chain and Block Chains to Increase the Country Revenues via Virtual Tax Transactions and Replacing Future of Money. International Journal of Suplly Management.Volume 8 No.5 August 2019.

Kasmir. 2010. Dasar-dasar Perbankan.Jakarta: PT. Raja Grafindo Persada.

Longenecker, G Justin et al. 2008. Kewirausahaan Manajemen Usaha Kecil (Edisi II). Jakarta: Salemba Empat.

Marihot, Manullang. 2001. Manajemen Sumber Daya Manusia. Yogyakarta: BPFE.

Marjani. (2005). Hubungan Motivasi Kerja dengan Kinerja Pegawai pada Unit Pelakasaan Teknnis Dinas PerhubunganPropinsi DKI Jakarta. PPs Institut Pertanian Bogor.

R. Nur Ilham, M.Sumatrani Saragih, and A. Saifannur, "Effect Of Working Capital Management And Leverage On Company Value With Profitability As Moderating Variables: Empirical Study on Manufacturing Companies Listed on the Indonesia Stock Exchange", IJEBAS, vol. 1, no. 1, pp. 41-53, Oct. 2021.

Permana, Fahmi. (2009). Pengaruh Motivasi Ekstrinsik dan Motivasi Intrinsik Terhadap Kinerja Para Sekaran, Uma. 2011. Research Methods For Business (Metode Penelitian Untuk Bisnis). Jakarta: Salemba Empat.

Priyatama, A. N. 2009. Peran Motivasi Intrinsik terhadap Komitmen Organisasi Karyawan. Psikohumanika, 2 (2): 1-9.

Ramadhani, N. T., \& Nurnida, I. (2017). Pengaruh Mata Kuliah Kewirausahaan Terhadap Minat Berwirausaha Mahasiswa. Jurnal Ecodemica, 93.

Rosidah. (2009). Manajemen Sumber Daya Manusia. Yogyakarta : Graha Ilmu.

Sadalia, I, Syahyunan dan Butar-Butar, N A. 2017. "Financial Behavior and Performance on Small and Medium Enterprises in Coastal Area of Medan City", IOP Conf. Series Materials Science and Engineering 180 (2017) 012257. Medan.

Sadono Sukirno. 2008. Mikroekonomi: Teori Pengantar. Edisi Ketiga. Jakarta: PT. Raja Grafindo Persada.

Sugiyono. 2008. Metode Penelitian Kuantitatif Kualitatif dan R\&D. Bandung : ALFABETA.

Suwatno dan Donni Juni Priansa. 2011. Manajemen SDM dalam Organisasi Publik dan Bisnis. Bandung: Alfabeta.

Thomas W Zimmerer, Norman M Scarborough, Kewirausahaan dan Manajemen Usaha Kecil, Salemba empat, 2008. 